Vietnam Academy of Science and Technology
Vietnam Journal of Earth Sciences
http://www.vjs.ac.vn/index.php/jse

\title{
Preliminary assessments of debris flow hazard in relation to geological environment changes in mountainous regions, North Vietnam
}

\author{
Tran Van Tu*, Dao Minh Duc, Nguyen Manh Tung, Van Duy Cong \\ Institute of Geologial Sciences, Vietnam Academy of Sciences and Technology
}

Received 7 April 2016. Accepted 15 August 2016

\begin{abstract}
Debris flow, widely viewed by geo-scientists as a special combination of landslide and flash flood, causes devastating damages to people and environment in northern mountainous regions of Vietnam. Field observations in the areas damaged by debris flows in northern Vietnam identified types of soils and rocks that were more likely to cause debris flows. Unlike flash floods, almost debris flows occurred at the end of the rainy season when soils and rocks were water-oversaturated thus mechanically weak; this is when pore water pressure decreases, lowering the strength from the soil. Landslides causing debris flows are commonly current slides. The tip of a landslide is often confined within a stream that has a permanent or seasonal flow. Debris flows mainly occur in proluvium, colluvial deposits or tectonic breccia zones. However, not a debris flow initiated in a tectonic breccia zone has been recorded in the northern mountainous regions of Vietnam. Colluvial deposits have been intensively investigated by many researchers worldwide. These deposits are commonly formed in neo-tectonic active zones, weak bed rocks, particularly old metamorphic rocks such as sericite shale, terrigenous and Cenozoic or late Mesozoic volcanic sedimentary rocks that are distributed at steep slopes and/or highly differentiated reliefs. These features appear to be a prerequisite for the exogenous processes, including rolling stones, falling rocks, landslides and surface erosions to occur. To study the mechanical and physical properties of colluvial deposits, the most practical approach is conducting experiments with large-sized samples or on-site experiments. However, this approach is expensive and not always favorable. Applying the rock mechanical theory, it is possible to examine $C, \varphi$ values if values of geological characteristics of rock blocks are known. Thus, the present study attempts clarify the cause-feedback relationship between the change of geological environment and geological hazard in general, and debris flows, in particular, providing a basic scientific insight for studying and predicting debris flows.
\end{abstract}

Keywords: debris flow, slope-flash flood, colluvium, prolluvium, flash flood.

C2016 Vietnam Academy of Science and Technology

\section{Introduction}

Debris flows (DF) are among the most devastating natural disasters in mountainous

*Corresponding author, Email: tranvantu92@yahoo.com.vn regions of Vietnam, especially in the northern part. The DF may be viewed as a special form of flash flood with a bulk density exceeding $60 \%$. The hazard lies not only in the enormous mudflow but also the falling of 
T. V. Tu, et al./Vietnam Journal of Earth Sciences 38 (2016)

massive rock blocks of several meters in size. The flow of rock blocks downhill will entrain masses of rock boulders and collide with objects on the way, including infrastructures, houses, irrigation and transportation systems, etc. Almost flash floods caused grave damages to people and properties in the northern mountainous regions in the past were debris flows. The DF occurred in Muong Lay in August 1996 was the first to be witnessed by survivors and videotaped Subsequently. Debris flows were also recorded in Nam Coong (Sin Ho, Lai Chau) in October 2000, Tan Nam (Xin Man, Ha Giang) in July 2002, Du Tien (Yen Minh, Ha Giang) in July 2004, Khen Len (Pac Nam, Bac Kan) in July 2009, Nam Luc (Bac Ha, Lao Cai) in September 2012, and Ban Khoang (Sa Pa, Lao Cai) in September 2013. Besides the Muong Lay town, debris flows occurred in remote and isolate areas. It took a long time for the emergency call to reach the local authorities to send help to the disaster areas.

This study aims to examine the causes and mechanisms of debris flow formation and development processes. This type of natural hazards is widely known by experts as difficult to predict although damages caused to humans, properties and the environment are usually enormous. The study provides preliminary assessments of the formation and development of debris flows in Vietnam (e.g. Tran et al., 2004) following a number of field surveys under the national project KC08.09/11-15 while referring to previous studies of colluvium in Asia and elsewhere in the world (e.g. Bauziene, 2000; Irfan and Tang, 1992; Lai, 2011; Gray, 2008; Fleming and Arvid, 1994).

\section{Debris flow characteristics}

Debris flows are formed and developed by a combination of flash flood and masses of soils and rocks. It is essential to distinguish between "mud-rock flow" and landslide. Although the large landslides occur during heavy rainfalls but they do not be able to form a debris flow. Examples of debris flows and flash floods occurred in Muong Lay Town (August 17, 1996), Nam Luc (2012), and Ban Ly (Du Tien, 2004) are shown in Figures 1, 2 , and 3 respectively.

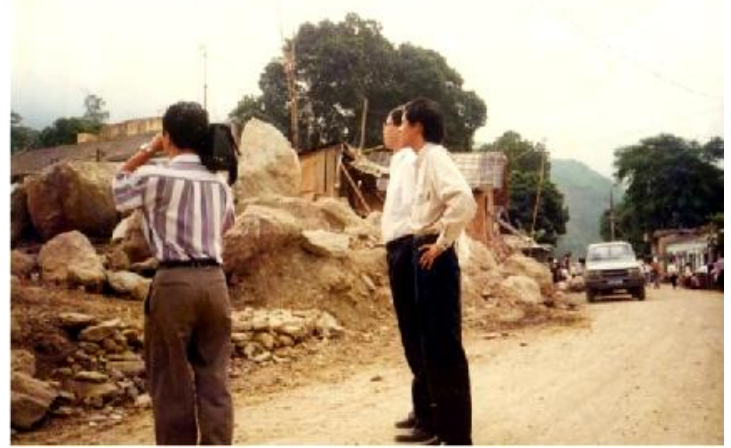

Figure 1. Debris flow in Muong Lay Town (Photo in 8/1996, immediately after a debris flow)

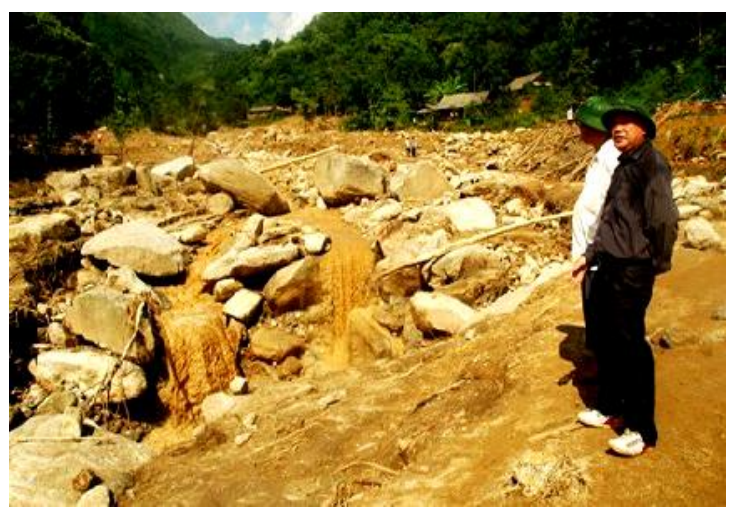

Figure 2. Debris flow in Nam Luc (Photo in 9/2012, immediately after a debris flow)

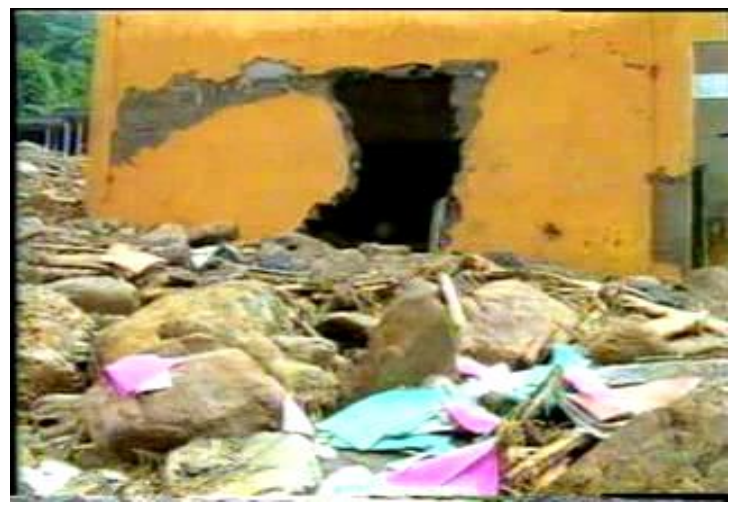

Figure 3. Effects of a debris flow on houses in Ban Ly, (Photo in $8 / 2004$, immediately after a debris flow) 
Some noticeable features of the debris flows are as follows:

(1) Most debris flows occur in remote areas where transportation and communication systems are less developed, thus difficult to issue warning and help.

(2) Debris flows occur in areas where surface or temporary runoffs are channeled.

(3) Prior to debris flows' occurrence, it rains for a long time, causing soil wateroversaturated and become mechanically weak under the effect of pore water pressure. Debris flows often occur at the end of the rainy season, e.g., August, September, or even October in the northern of Vietnam.

(4) Dense mud-rock flows run down to the mouth of a stream with enormous force. Downstream areas are favorable places for human settlement; therefore, the damages by debris flows are mostly effecting people.

(5) Large boulders with sizes up to several meters entrained by debris flows being pushed downward by flow currents appear to be a major factor in destroying houses, transportation and irrigation systems (Figure 4).

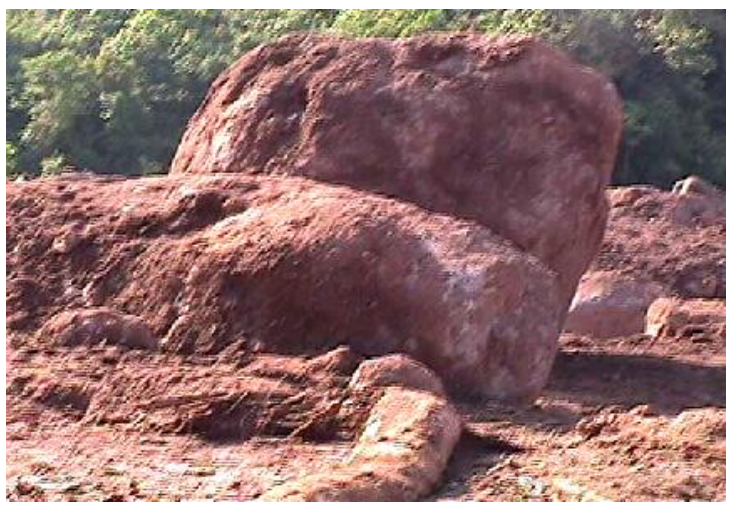

Figure 4. Debris flow in Nam Coong (Photo in August 2000 , immediately after a debris flow)

\section{Engineering geological characteristics of debris flow areas}

Firstly, debris flows occurred in areas having slopes as steep as $25-35^{\circ}$. Slope steepness and terrain differentiation define the potential energy of rock masses. These slopes are steep enough for flash floods to happen.

The geology of northern mountainous regions of Vietnam where debris flows commonly occurred includes relatively soft formations, comprising mainly of Late Neoproterozoic to Early Cambrian schists, Cenozoic and late Cretaceous terrigenous and volcaniclastic sediments. Late Cenozoic tectonic activities have created main characteristics of topography, distribution of rivers and streams network, as well as weathered activities in the north Vietnam (Ngo et al., 2016). In the Lo village (Muong Lay) exposed is Nam Co complex $\left(\mathrm{NP}_{3-\varepsilon 1} n c\right)$ composed of sericite schist, sericite-quartz schist, two-mica-quartz schist. In the Nam Coong village outcropped is intercalation of conglomerates, sandstones and siltstones of Yen Chau Cretaceous formation $\left(\mathrm{K}_{2} y c\right)$. The cements of the conglomerates and siltstones are subjected to weathering, leaving sandstones to form large boulders. In the Lung Chun village area (Xin Man, Ha Giang), cropped out are muscovite-feldspar-quartz schists of the Thac Ba formation (NP $t b$ ), and coarse-grained biotite- gneiss-like granites of the Song Chay complex $\left(\mathrm{PR}_{2-\varepsilon 1} s c\right)$. In the Ly village, found is lower Mia Le formation $\left(\mathrm{D}_{1} m l\right)$ comprising brownish-red shale, carbonate clayish shale, and carbonate clay. A geologically significant feature of these areas is the strong activity of recent geodynamics (Tran el al., 2004).

Figure 5 shows locations of debris flows in a modern geodynamic plan in the northern mountainous regions. It is obvious that a large number of debris flow occurrences are in the neotectonic active zone. Figure 6 illustrates the appearance of debris flows is related to engineering geological characteristics of the bedrocks. The combined lithologic and recent geodynamic feature is considered as a very important geological factor for debris flows (Tran et al., 2004). The hydrometeorological 
T. V. Tu, et al./Vietnam Journal of Earth Sciences 38 (2016)

condition is another key factor to generate debris flows. Debris flows are "mud-rock flows" although the force is not comparable to that of flash floods. Figure 7 shows some locations of debris flows having occurred on the flash floods' distribution map. This is a synthetic map based on the hydrological zoning map of northern Vietnam (1985), which summarizes factors that may generate flash floods (Tran Van Tu et al., 1999).

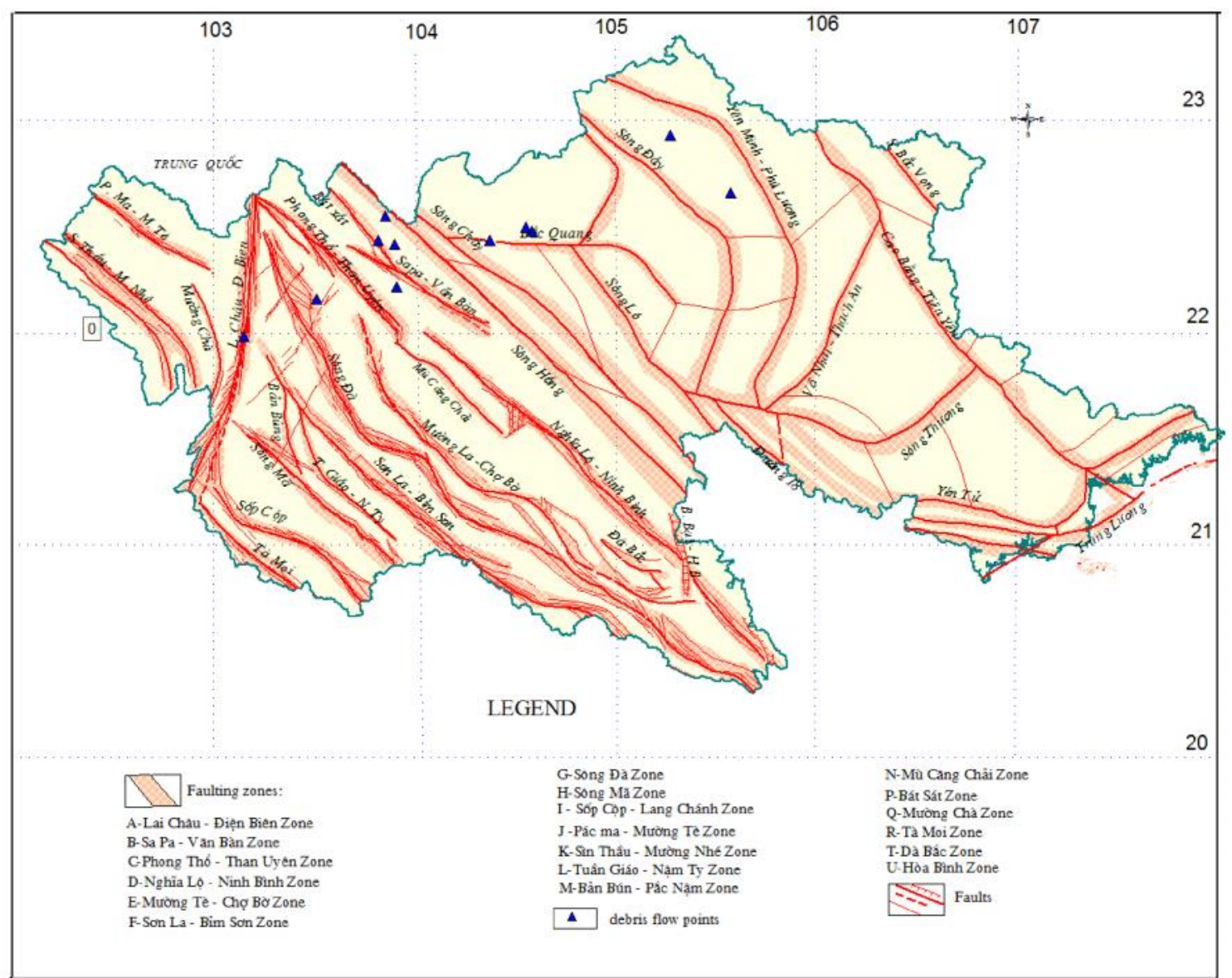

Figure 5. Relationship between neo-tectonic faults and debris flow in the northern mountainous regions (Tran et al., 2004)

Another factor that is crucial to generate debris flows is the engineering geological condition of the source rocks. Field surveys in the debris flow areas show that the northern mountainous areas of Vietnam have three rock types as follows:

(1) Proluvium deposits distributed in streambeds with relatively steep slopes. A proluvial layer is formed annually and accumulated at a certain altitude on the streambed. The favorable slope of a streambed to accumulate a proluvial layer is $5-10 \%$. For steeper slopes, the proluviumis likely transported and deposited at the mouth of the stream that intersects with larger rivers or intermountain valleys. The surface slope of a proluvium deposit is usually not steep. Proluvial layers have been accumulated in the streambed for the long time thus mechanically stablized. However, after being inundated the rock adhering cements will weaken due to the effect of pore water 
pressure. Figure 8 shows the structure of old coluvial-proluvial deposits above the proluvial proluvial deposits in the Nam Cham layer are main soil-rock supplying sources to streambed connecting to Nam Luc. The debris flows.

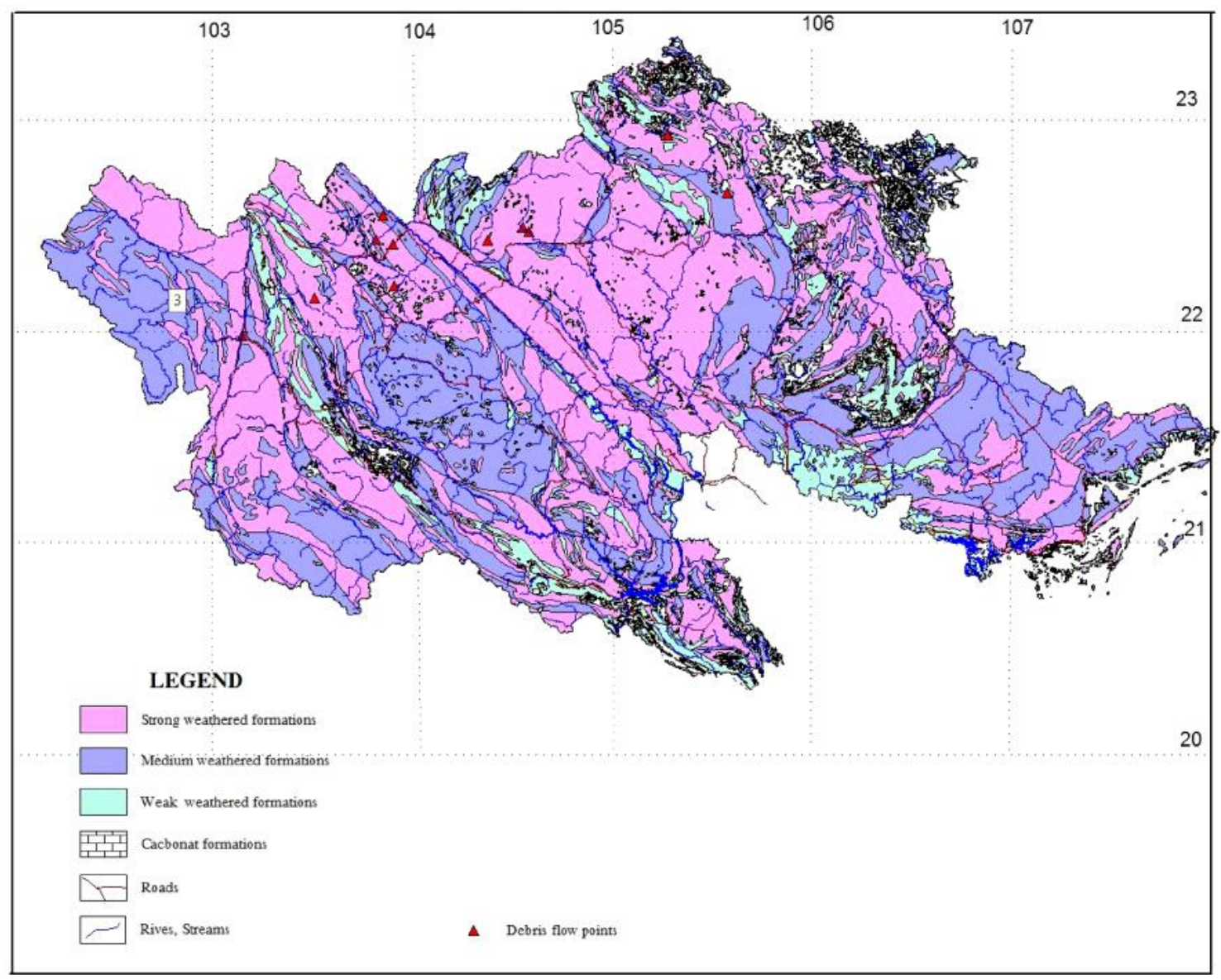

Figure 6. Relationship between debris flows and geoengineering characteristics (Tran et al., 2004)

(2) Colluvial deposits on the slopes and streambeds are accumulated materials from landslides, rolling stones, avalanches and other eroded products by rainfalls or water currents. These materials fill up streambeds, especially the temporary ones. During the rainy season, the groundwater level increases; given a suitable combination of surface runoffs and groundwater flows, these can cause stream-slides and debris flows. Colluvial deposits are recognized by many researches elsewhere in the world (Bauziene, 2000; Irfan and Tang, 1992; Lai, 2011; Gray, 2008; Fleming and Arvid, 1994).
They are formed by a mixture of deposited products of landslides, rolling stones, falling rocks, eroded materials by rainfalls and surface flows (Bauziene, 2000). The colluvial layer is a weak agglomeration of sandstones, gravels, fragmented rocks, boulders, and rock blocks. Despite a number of studies of colluvial deposits but most have focused on some particular topics serving investigation of landslide stabilization, erosion and transportation foundation (Gray, 2008). Our field studies showedthatcolluvial deposits in Nam Luc, Khen Nin, Lung Chun are a mixture of slope accumulated deposits with 
T. V. Tu, et al./Vietnam Journal of Earth Sciences 38 (2016)

rolling and falling stones of diverse sandstones derived from terrigenous lithologic compositions, including sediments of Yen Chau formation. Colluvial terrigenous sediments and volcaniclastic deposits at Lo stream (Muong Lay) contain sediments with boulders up to $100-120 \mathrm{~cm}$ in mainly slope boulders and slope sediments size. Colluvial deposits in Nam Coong supplied by metamorphic rocks of Nam Co comprise slope sediments, rolling stones formation. The boulders vary widely from including pebbles, boulders, weathered $20-30 \mathrm{~cm}$ to $100-120 \mathrm{~cm}$ wide (Figure 8-10).

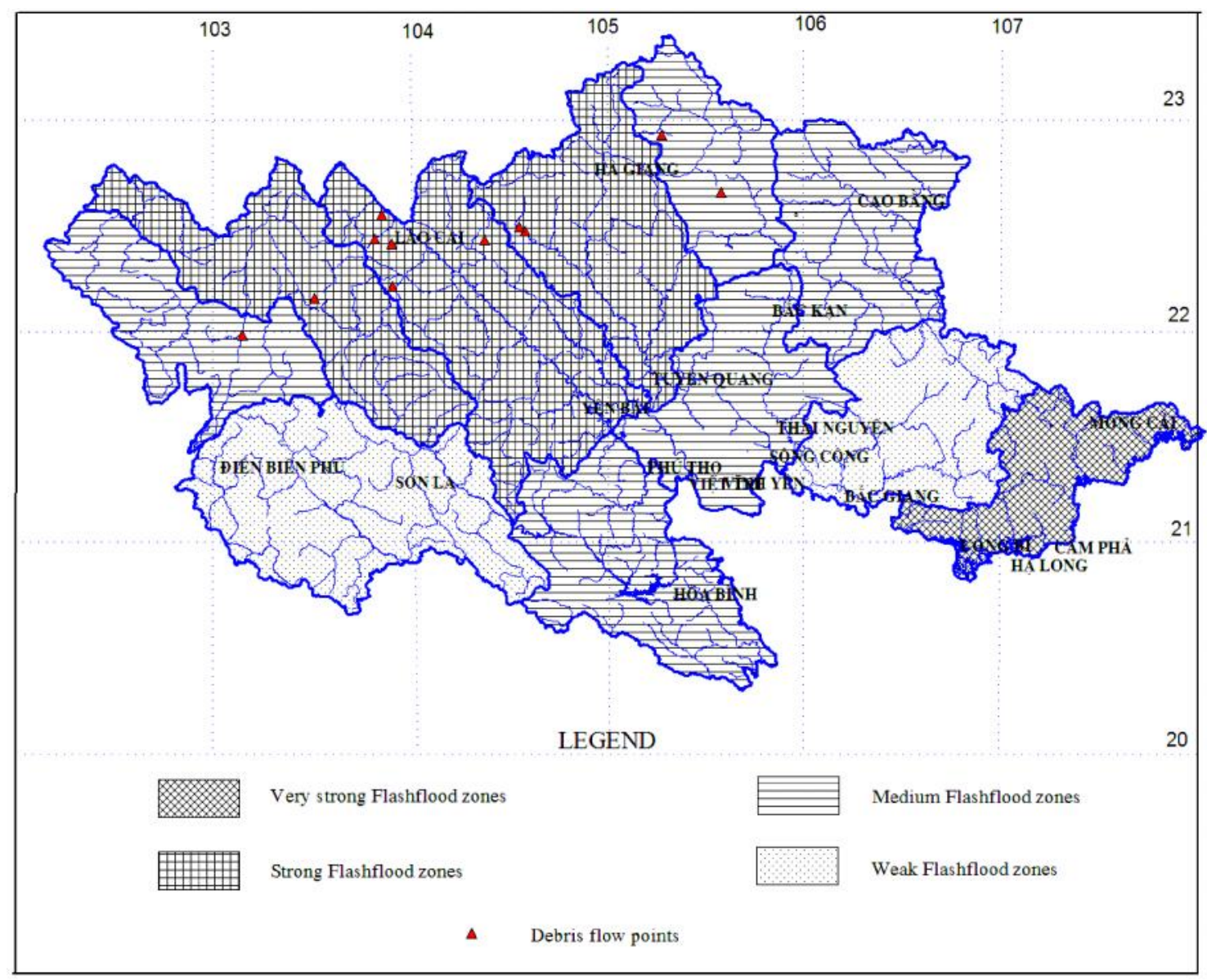

Figure 7. Distribution of flash floods and debris flows (Tran Van Tu et al., 2012)

(3) Weathered tectonic breccia deposits are formed by regional faulting activities. The products include soil-rock fragments, formed by tectonic compression, or sedimentary debris falling into faults. The weathered rocks become unconsolidated thus easily absorbed by water. These products are observed in areas along tectonically strong active zone such as the Dien Bien-Lai Chau zone, Da River, Lo River and Chay River fault zones.
However, determination of distribution regulation of these products appears to be rather difficult. Despite the tectonic breccia layer zone being mechanically weak and having a relatively steep relief, but because of being narrow and covered by hard rock. Therefore, in a normal condition, it may not occur a landslide. However, in some certain condition, a stream-slide may be generated even without rain. 
Vietnam Journal of Earth Sciences Vol 38 (3) 231-241

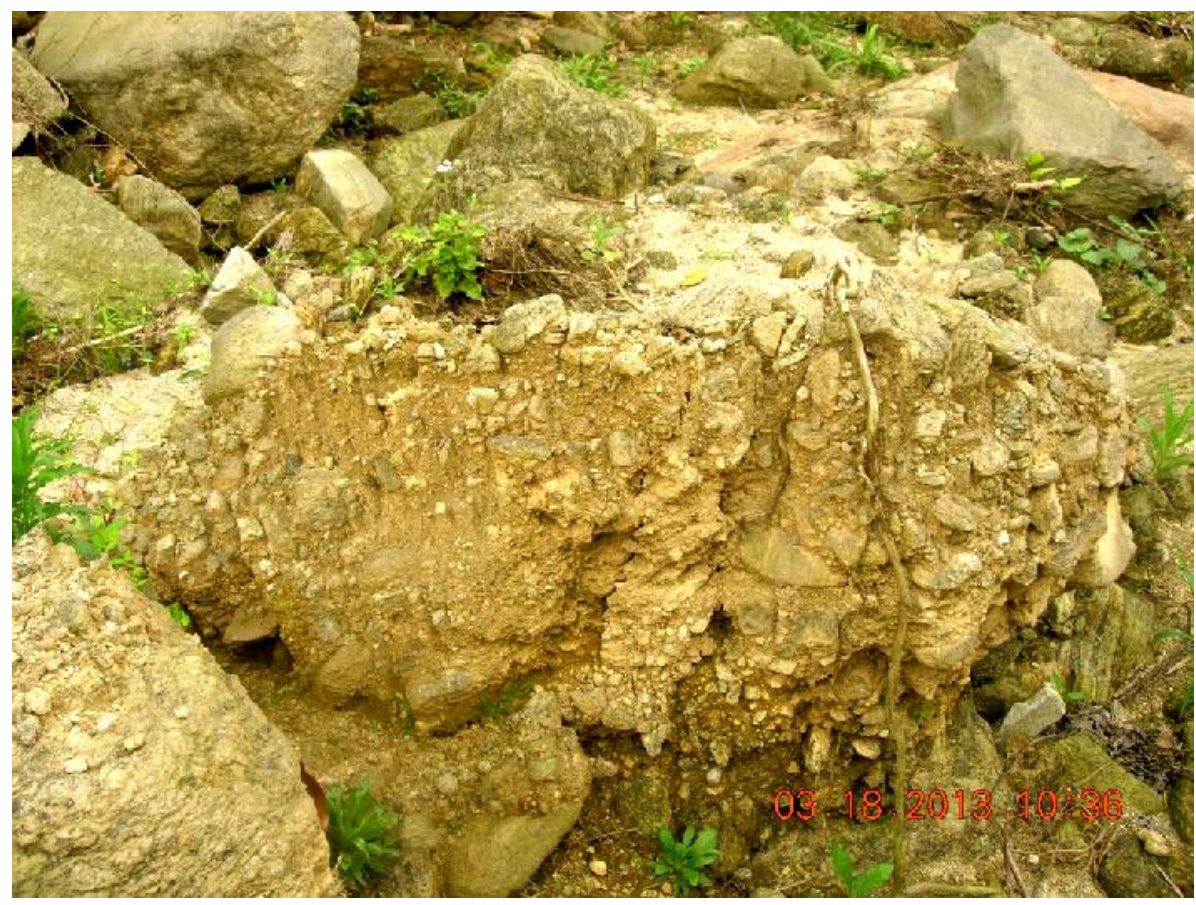

Figure 8. Old proluvium deposit at Nam Cham stream, Nam Luc, Lao Cai (Photo in March 2013, 6 months after the debris flow disaster)

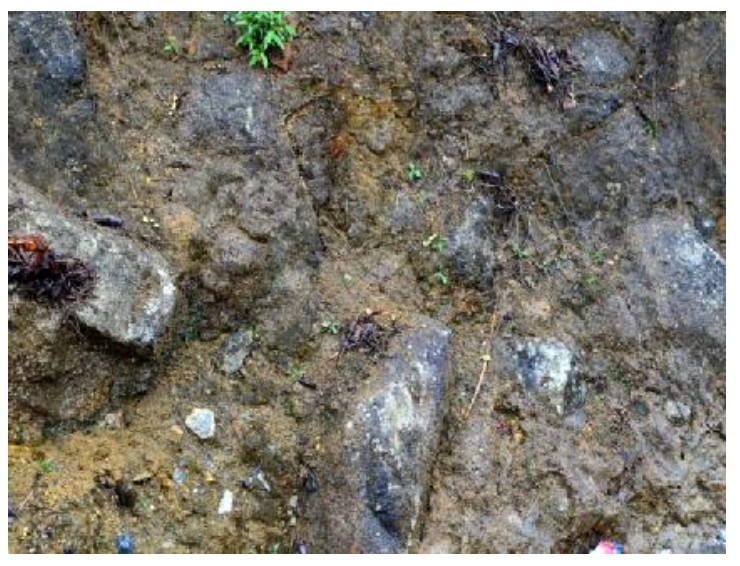

Figure 9. Colluvial deposits along the road from Tam Duong to Lai Chau (Photo in January 2015)

At the present, there are only a few comprehensively engineering geological studies of colluvial deposits not only in Vietnam but even in the world. A study of colluvial deposit in Hong Kong (Lai, 2011) revealed formation stages at middle-late Pleistocene or Holocene. The author reported several experiments of dried densities for several colluvialdeposits, showing for the Holocene, late Pleistocene, and middle Pleistocene colluvium were $12.6-13.8 \mathrm{KN} / \mathrm{m}^{3}$, 15.8 to $16.6 \mathrm{KN} / \mathrm{m}^{3}$, and $16.3-18.9 \mathrm{KN} / \mathrm{m}^{3}$, respectively. Relative moisture ranged between $12 \%$ and $20 \%$.

Breccia and fragmented rocks of colluvial deposits in the tropical humid condition, in difference to those in the sub-tropical region, can be lateritized to form secondary adhesive cements, which enhance the mechanical strength of the block. The tropical colluvial deposits, however, are less stable under the effect of pore water pressure.

Irfan and Tang (1992) summarized the results of reported experiments including direct sample cuttings, use of large samples, 3-axial cuttings and in-situ experiments to determine the effect of coarser grains on the strength of colluvial deposits. Using halfcentury old, since the $20^{\text {th }}$ century, experimental data the authors concluded that: 
T. V. Tu, et al./Vietnam Journal of Earth Sciences 38 (2016)

The amount of coarse-grained constituents affects the strength of colluvial deposits;

The effect of coarse-grained materials is ignorable if containing $<20 \%$, low if the proportion ranging from 20 to $30 \%$, and significant if the proportion of coarse grained materials is more than $30 \%$.

The effect is proportional to the amount of coarse-grained components; however, this concept is difficult to substantiate.

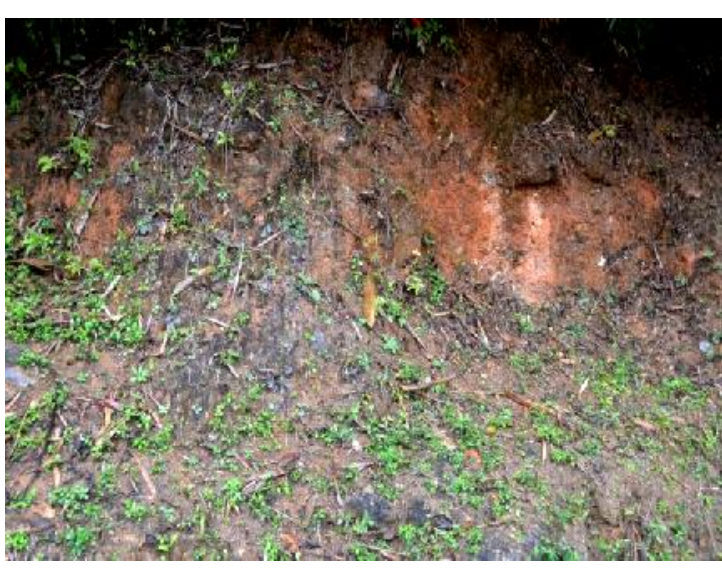

Figure 10.Colluvial deposit along the road from Dien Bien to Tay Trang (Photo in January 2015)

In summary, the test results of large block cutting and field experiments, the authors reported the mechanical indicators for colluvial deposits in Hong Kong as follows: $\mathrm{C}=2.5-12.5 \mathrm{KPa}, \varphi=15-45^{\circ}, \sigma_{\mathrm{n}}<50 \mathrm{KPa}$. These mechanical indicators suggest that colluvial deposits are different from common sediments. Based on the rock mass classification theory, e.g., 'Geological Strength Index GSI' one can calculate $\mathrm{C}$ and $\varphi$ values for colluvial deposits (Hoek and Marinos, 2007).

The studies of colluvial deposits (Bauziene, 2000; Irfan and Tang, 1992; Lai, 2011; Gray, 2008; Fleming and Arvid, 1994) all agreed that their mechanical properties decrease largely in the water saturated condition. This is an important factor determining geological hazards, particularly landslides and debris flows.

\section{Debris flow forming mechanisms}

As mentioned above, debris flows usually occur after prolonged rains. All the debris flows recorded previously occurred at the end of rainy season (e.g. August, September, even October in the Northern of Vietnam). During this rainy period, the soil-rock blocks had reached maximum water-saturation point and the pore water pressure had risen to the highest values to reduce the mechanical strength of the rock masses. Groundwater in the colluvial or proluvial deposits can be static or dynamic. Amount of water leaking out on the slope cover may serve as a direct value for calculating the groundwater discharge in the soil-rock mass.

Thus, soil-rock deposits in a streambed or subsurface are firstly water-saturated. Heavy rain then forms surface flows that may or may not be reached the threshold of flash flood. The rock masses become unstable, as a result, slide down the slope. The combination of surface flows and unbalanced soil-rock masses forms a massive volume and sweep to the foot of the hill.

The rock blocks are increased kinetic energy of debris flows. Particularly, gravels, pebbles and rock boulders in the debris flow can move with great speeds, colliding with each other, making noises that can be heard from a far distance. The carried rock debris knock down and sweep away houses, crops, people and animals on its flashing path.

Debris flows only terminate at a horizontal plain or river valley at the mouth of stream. The entire stream mouth area can be buried under mud and rocks, so are humans and their properties. With mud-rock mixed masses, the depth can reach up to 4-5 $\mathrm{m}$ and thousands of square meters large. For example, the buried area by 1996 debris flows in Muong Lay was hundreds of meters wide. The buried areas in Ban Cham (Nam Luc, Lao Cai) and Ban Khoang ( $\mathrm{Sa} \mathrm{Pa}$, Lao Cai) were narrow and lengthened along the streams made it difficult to search and rescue for the human casualties. 
Stream-slides ccurring without heavy rains may not form debris flows but they can cause significant damage to people and properties. The Phin Ngan (Bat Sat, Lao Cai) slipstream occurred in September 2004 and the Ngan Vang (Binh Trieu, Quang Ninh) disaster happened in June 2005 killing 23 and 11 people, respectively, are clear examples.

\section{Post debris flow hazard geological environment changes}

Debris flows are disastrous that gravely effect the local environment. Although the effect on the natural environment is not large as compared to obstructed sweeping floods (Tran Van Tu, 2012), but tends to make the greater impact than the flash floods. Firstly, debris flow can cause people casualties, sometimes a whole village in a mountainous area can be destroyed. The debris flow disaster is as equally dreadful as a mixed flash flood (Tran Van Tu, 1999). Fortunately, as local people have become more aware of the danger caused by flash floods they are more knowledgeable in keeping themselves safe, thus human casualties are gradually reduced. However, human casualties by debris flow hazards are unpredictable, not only because they frequently happen in remote and isolated areas, where transportation and communication systems are inadequate, but also because of the graveness of this type of hazards. Secondly, debris flows can cause significant costs to the economy. Some debris flow had swept a whole village along with its cropland and productivities. The biggest consequence of a post debris flow disaster is resettlement of villagers away from their original residential site. Because their houses, roads and other essential infrastructures were buried that impossible to recover. Typical examples of disasters of this scale include Muong Lay (1996), the town was resettled at a new place more than $50 \mathrm{~km}$ from its origin, Nam Coong, Nam Cham and Khen Nin villages were also moved to new sites. The resettlement process is not only economic cost but may also leave the residents with mentality suffering. Thirdly, debris flows pile up a large amount of sediments on the cropland, plains and gardens that take many years to restore. However, because debris flows often occur at the intersection of small and large streams where floods can wash away the sediments so that the environment can be gradually recovered (Figure 11). For example, traces of debris flows occurred in the Ly village (Du Tien, Ha Giang) disappeared after a period of 10 years (Figure 12). Currently, the local people are planting corn on a rocky field, a remnant of debris flows. A rocky bed seen at a place along Route No12 from Dien Bien city to Lai Chau city after debris flows passed by Muong Lay in 1996 has disappeared.

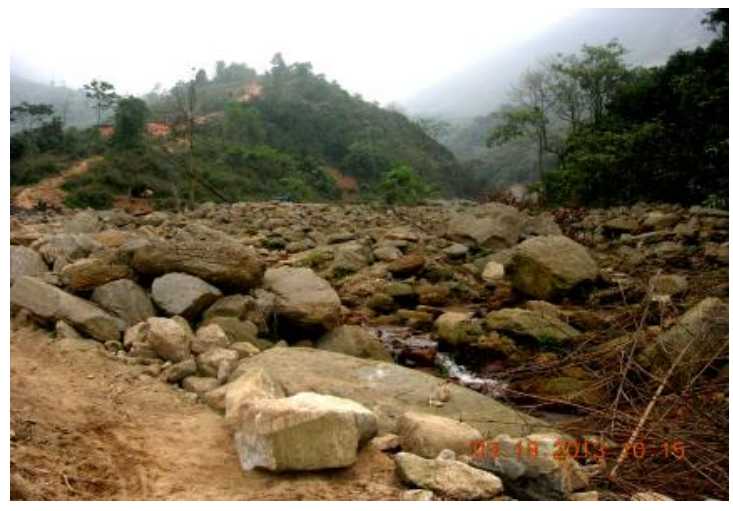

Figure 11. Rocks in Nam Luc (Photo in 2013, 6 months later a debris flow)

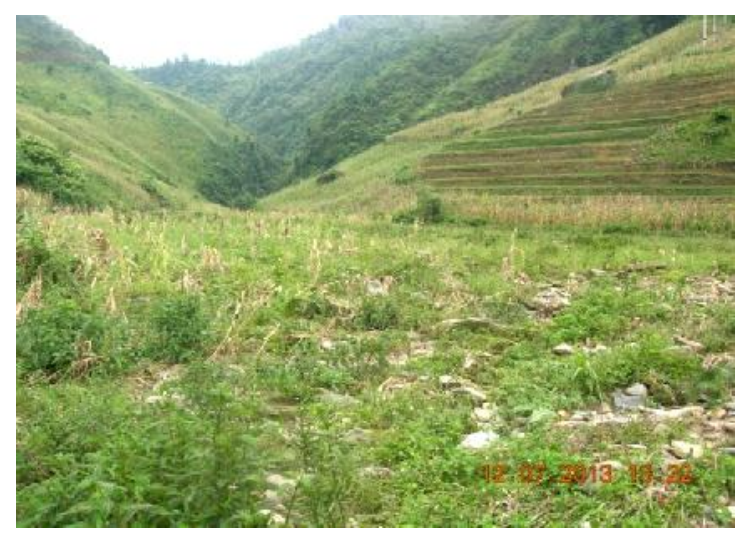

Figure 12. Rocks in Ban Ly (Photo taken 9 months later a debris flow) 
T. V. Tu, et al./Vietnam Journal of Earth Sciences 38 (2016)

\section{Conclusions}

Debris flows are disastrous that are difficult to predict due to forming condition localized and complicated. This is the main difficulty in warning and zoning forecast.

Debris flows in northern mountainous regions of Vietnam occur mainly in the proluvial and colluvial deposits or tectonic breccia zones. These soil-rocks mixed masses are weak and difficult to examine the geotechnical and engineering properties. They are stable during dry or suitable humidity condition, but become instable under watersaturated conditions, effected by fast surface flows or earthquakes.

To mitigate the damage by debris flows, it is recommended that people should live far away from the mouth of stream containing proluvial or colluvial deposits. Communication means from remote residential areas to the nearest administrative headquarters must be established. Villages inhabited on colluvial deposits need to resettle to a more stable area.

In an about 10 year duration after debris flow occurrence, the rocky beds can be covered by soil layer thanks to the environmental self-recovery (or) in combination with human efforts. At the less important sites, it may not be necessary to invest generously in recovery.

\section{Acknowledgments}

This paper was completed on the basis of research achievements of the project KC.08.09/11-15.

\section{References}

Bauziene L., 2000. Colluvisols as a component of erosional and accumulative soil cover structures of east lithuania. European soil Bureau - research report (7), 147-151.

Hoek E., Marinos P., 2007. A brief history of the development of the Hoek-Brown failure criterion, Soils and Rocks, 2, $1-8$.

Irfan T.Y., Tang K.Y., 1992. Effect of the coarse fractions on the shear strength of colluvium. Geo report No 23, Geotechnical Engineering office, Civil Engineering Department Hong Kong.

Lai K. W., 2011. Geotechnical properties of colluvial and alluvial deposits in Hong Kong. The $5^{\text {th }}$ cross-strait Conf on Structural and geotechnical engineering (SGE-5), 735744, Hong Kong China, 13-15 July 2011.

Ngo Van Liem, Phan Trong Trinh, Hoang Quang Vinh, Nguyen Van Huong, Nguyen Cong Quan, Tran Van Phong, Nguyen Phuc Dat, 2016. Analyze the correlation between the geomorphic indices and recent tectonics of the Lo River fault zone in southwest of Tam Dao range, Vietnam Journal of Earth Sciences, 38(1), 1-13.

Richard E. Gray, 2008. Landslide problems on appalachiancolluvial slopes. Geohazards in transportation in the appalachian region, Charleston, WV.

Robert W. Fleming, Johnson M. Arvid, 1994. Landslide in Colluvium. U.S. geological Survey Bulletin 2059-B.

Tran Trong Hue (edit), 2004. Integrated assessment of geological disasters in Vietnam territory and prevention solutions (Phase II: The northern mountainous provinces), Report on Phase II of the Independent National project. Institute of Geology, Hanoi, 2003.

Tran Van Tu (edit), 1999. Study of the scientific basis of formation and development of mountain floods (including flash floods), proposing the solution of warning, mitigation, and reduction of natural disasters and damage. Report of the project of the Vietnam Centre for Science and Technology, 1998 - 1999.

Tran Van Tu, 2012. Scientific basis and method to set up the map of zonation area for sweeping flood, Journal of Sciences of the Earth, 34(3), 7-13. 